\title{
Treatment of Textile Waste Water using Different Local Absorbents
}

\author{
Muthukannan M, Arunkumar K, Maheswari M
}

\begin{abstract}
The waste water resulting from textile industries is a major environmental pollutant, and it can also contaminate soil, when deposited on the ground. There are various commercially available adsorbents for treatment of waste water, however, cheaper alternatives are being proposed in this study. Waste water, highly alkaline and high in suspended solids and colour, was used for the investigation. Different proportions of local materials, sugarcane bagasse, saw dust, maize, and lime stone, were utilized in the process, thus, with a view to ascertain their efficiency to modify the water properties: colour, turbidity, sulfate, chromium, iron, Chemical Oxygen Demand, and Biochemical Oxygen Demand. While a dosage of 1-5 $\mathrm{ml}$ per $250 \mathrm{ml}$ of sample was added for the adsorption process, activated carbon was replaced with each natural adsorbents by $0-100 \%$ replacement at $20 \%$ intervals and added to the sample water. The optimum adsorbent dosage was obtained by making many trials with different dosages and different $\mathrm{pH}$. The adsorption process was done by using adsorption column. The results showed that the alternative materials studied, could be used effectively for treatment of textile industrial waste water, with performance similar to the conventional adsorbents.
\end{abstract}

Keywords : waste water, adsorbent, activated carbon, textile dye, eco-friendly.

\section{INTRODUCTION}

Te extiles, on a global consumption rate, is currently around 30 million tones, it is reported that its consumption is expected to grow at 3\% per annum (Walker and Weatherly, 1997). For 30 million tons of textile, an approximately 8 times of hundred tons of dyes are demanded for its coloration (Walker and Weatherly, 1997). Dyes and pigments of about 10,000 types were generated annually in worldwide (Asamudo et al., 2005), in that azo compounds are more which is liked to azo bridge. Besides the use of the compounds by textile mills, azo dyes can also be generate from various industries (Asamudo et al., 2005). Note worthily, from the measure of synthetic textile dyes utilized each year during material generation process, $20 \%$ of these colours end up in the earth through effluents, those outcomes from the treatment of remaining industrial waters. The wastewater resulting from printing and dyeing processes was color rich and also contains buildups of responsive colors and synthetic substances, this features makes it necessary that this

Revised Manuscript Received on December 30, 2019.

* Correspondence Author

Muthukannan $\mathbf{M}^{*}$, Department of Civil Engineering, Kalasalingam Academy of Research and Education, Tamil Nadu, India. Email: civilkannan@gmail.com

Arunkumar K, Department of Civil Engineering, Kalasalingam Academy of Research and Education, Tamil Nadu, India. Email: arunapcivil@gmail.com

Maheswari M, Department of Civil Engineering, Kalasalingam Institute of Technology, Tamil Nadu, India. Email: maheswaricivil222@gmail.com

kind of waste water be treated before discharged into the earth. According to effluent proceed by a responsive color, contains hydrolyzed reactive dyes which are not fixed on the substrate, but represents about $20-30 \%$ of the responsive colors. The residual amount of reactive dye in a wastewater is responsible for the coloration of the effluents and cannot be recycled. While, the unrecyclable dyed organic substances is responsible for causing a high biological oxygen demand (BOD), and chemical oxygen demand (COD) of the effluents. Also, textile fibers, containing 60-100 g/l electrolytes, sodium chloride and sodium carbonate, are constitute a very high saline content of any wastewater (Allegre et al., 2006). Besides dyes, textile production wastewater also contains solids, oil, and halogenated organics, which are resulting in the bleaching activities. The compounds applied to fibers in process of washing, while trying to improve its properties, are sometimes released into effluent water during washing. A sizing compound, such as starch, contributes to increasing the biological oxygen demand (BOD) and chemical oxygen demand (COD) of wastewater stream. However, a synthetic sizing additive, which is not as biodegradable as starch, can pass through conventional wastewater treatment system, and are often linked to aquatic toxicity in receiving water. The toxic, acidic or alkaline nature of dye, and some other organic compounds, which comes from industrial sectors, makes the waste water harmful to the environment. Thus, increasing public concern about the environmental impacts of such wastes has caused wind up of several small-scale industries. In recent years, interest of production technology of textile by wet process has increased due to increase in the public awareness of its environmental friendly nature. Textiles of biodegradable and eco friendly were demanded by the foreign consumers, (Chavan, 2001). However, the case is different with dyes, it is ominous from a natural perspective, in light of the fact that the effluents created amid its utilization, are intensely shaded, contain higher groupings of salts, BOD and COD.During dyeing of textiles, there are standard considerations for ecological friendly production, from raw material selection to the final production, which are supposed to be put in place. The production process can be improved upon, so that, they are made more ecologically friendly, and at a lesser processing cost. For an environmentally friendly production, it entails the use of safer dyes, chemicals and by reducing cost of effluent treatment and disposal. Activated carbon is a popular adsorbent, which is commonly used for wastewater treatment. However, due to its high cost, and also considering the quantity of activated carbon that are required for treatment of large volume of effluents produced by textile industries, therefore research attention is focused on finding alternative adsorbents (Ghanshyam G. Pandhare et al., 2013). 
A number of agricultural wastes, coir pith, banana pith, sugar cane dust, sawdust, and rice hulls (SunilKumar et al.,2008), have been used as adsorbents. An effective and economical waste water treatment is necessary, to control pollution and the release of toxic substance into the environment, during textile and dyeing operation. Therefore, the current study is germane, because it focusses on treatment of textiles and dyeing industrial effluents, using locally sourced materials. Highly alkaline waste water, which is discharged from a dying unit situated in Tirupur district, India is used in this study.

\section{A. Impact of dye waste on the environment: a scenario of tirupur, India}

As a result of the post liberalization period in the Indian economy, there was a rapid development in the cotton textile and garment industries. This consequently accounts for a major share of Indian exports. A report of the Ministry of textiles (1999) showed that the percentage of exported textiles, has increased by $14 \%$, over the total exports from India, this also represents about $4 \%$ of GDP (Ministry of textiles, 1999). During the year 2005 to 2006, the export earnings from Tirupur were about Rs.10, 250 cores (Nelliyat, 2007), which showcased the signicant contribution of this industry to the Indian economy. Tirupur, where major knitwear production industries are located in India, currently holds more than 9000 small-scale units, which are responsible for production of one-third of the total apparel exports from India (Swaminathan and Jeyaranjan, 1995). Within the last few decades, the wet processing (bleaching and dyeing), a sub sector of the hosiery industry, have increased to 729 units in Tirupur. As a disadvantage to the environment, effluents, containing chemicals used during the bleaching process, are discharged in to nearby rivers. As such, the chemical ends up as pollutant and contaminant, which destroys the biodiversity in the environment.

Water is one of the essential materials used during textile processing. As at the year 2000, the measure of water used by these ventures has expanded to 86 million Liters for each day. Unfortunately, due to the increased pollution and contamination of the surrounding water in Tirupur, as a result of effluent discharges, there will be worst quality of water. Therefore, the required water for material preparing was sourced from encompassing towns using tankers. It is consequently pertinent that the polluted river water is systematically treated, so as to improve its quality and make it available for use. Therefore, this study proposes various alternative treatment mechanisms, which are developed with locally sourced materials.

\section{B. Waste water treatment via adsorption process}

Adsorption, a physico-chemical technique, is a process whereby ions or particles present in one stage change to accumulate and focus on another stage surface. When a weak intra particle bonds (such as Van der Wals' or hydrogen interaction) exists between adsorbents, the adsorption process is known as physical. However, the chemical adsorption process is the reverse of the physical adsorption, in that, solid interspecies bonds are available between the adsorbents. The role of adsorption in water and environmental processes was studied by Suzuki (1997), and some modernized treatment technique was proposed. Adsorbents are mostly a highly porous material, having small pores and an internal surface area which is greater than the external area. The utilization of adsorbent, among the various methods of color expulsion, gives an effective removal of various sorts of shading materials (Jain et al., 2003). The adsorption strategy for wastewater treatment, have turned out to be increasingly well known lately, owing to its proficiency in the expulsion of poisons that are not effectively biodegradable. For producing high quality water, adsorption can be quite good and financially effective.

\section{MATERIALS AND METHODS}

\section{A. Sample collection}

In this study, the wastewater used, was collected from a dyeing unit situated in Tirupur district, India. The textile industries in this area have a daily wastage of 20,000 litre. The industry consumes about 20,000 litre of water, as its intake and the whole water becomes a waste at the end of dyeing process. The total quantity of input water is converted into waste, and they are then transferring to some zero liquid discharge plants or common effluent treatment plants. This study aims to introduce newer technologies in the treatment plants, so as to make the treatment process efficient. The industrial wastewater treatment plants involve the units like screening, grit removal, and coagulation with sedimentation, filtration or aeration with biological treatment process, sludge removal, reverse osmosis process. The sampling of waste water was done at the main collecting tank, by using grab sampling method The sampling bottles are of 50 liter capacities, which are rinsed three times with tap water, followed by rinsing with distilled water and finally rinsed with $6 \mathrm{~N} \mathrm{HNO3,} \mathrm{for} \mathrm{removal} \mathrm{of} \mathrm{any} \mathrm{sign} \mathrm{of} \mathrm{pathogens} \mathrm{or} \mathrm{odour.}$ The samples collected are used immediately for the study.

\section{B. Preparation of Adsorbents}

The materials used as adsorbents in this study, includes sugarcane bagasse, sawdust, maize, and lime stone. Sugarcane bagasse was collected and cut into small pieces. It was rinsed several times using potable water, and dried overnight at a constant temperature of $60^{\circ} \mathrm{C}$ in the oven. The dried bagasse was ground and used an adsorbent. The gathered sawdust is from the neighborhood saw plant and sieved through $425 \mu \mathrm{m}$ sieve. To remove the particles in the surface, it was washed with refined water and dried at a temperature of $60-80 \mathrm{oC}$ in the stove. The crushed maize was sieved through a mesh of size $425 \mu \mathrm{m}$, and subsequently was stored in the plastic bottles. The gathered lime stone was from the adjacent quarry and sieved through $425 \mu \mathrm{m}$ sieve. At that point, it was washed with refined water to evacuate the surface followed particles and dried at a temperature of 60-80 oC in an oven.

\section{Experimental setup}

The Adsorption process was done using a 15 column adsorption setup. It consists of 3 rows and each row has 5 columns. The column dimension is $50.8 \mathrm{~cm}$ in height and 3.2 $\mathrm{cm}$ in diameter. The capacity of these columns was 408.557 $\mathrm{cm} 3$.

Published By: 
It has two nozzles of $12 \mathrm{~mm}$ diameter in the top and bottom of the column, for the purpose of inlet and outlet of the sample water as shown in Figure 1. The top nozzle serves as inlet for the column which is placed at $5.1 \mathrm{~cm}$ from the top of the column and the bottom nozzle serves as outlet for the collection of treated water, which is placed at the centre of the end cap. The inlet water was provided by using $0.5 \mathrm{HP}$ pump in a constant flow rate of $220 \mathrm{ml} / 1 \mathrm{hr}$. Each rows was filled with different type of adsorbent at different ratio of $(100,0)$, $(80,20),(60,40),(40,60)$ and $(20,80)$ in each column. This was run in two different connections, as series (Figure 1d) and individual connection (Figure 1 e), to identify the maximum efficiency of the adsorbents. Samples were drawn at a regular interval, in order to check the TDS, $\mathrm{pH}$, iron, transmittance, conductivity, chromium, COD, and sulfate, as per APHA standards (APHA, 2000). All the tests were performed in triplicates, and analysis of result was performed by the consistent values.

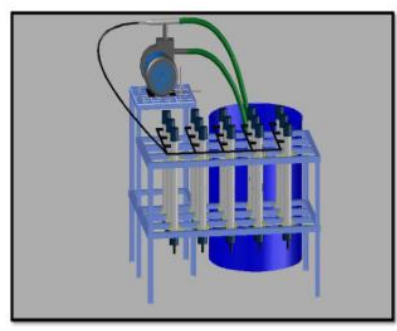

Fig 1 a

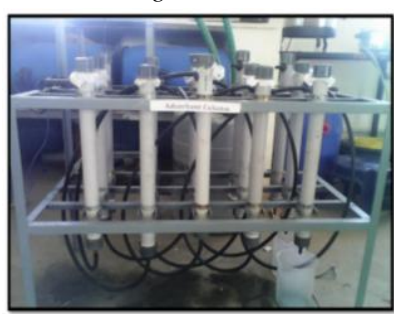

Fig $1 c$

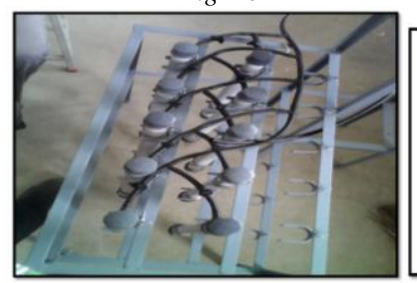

Fig 1 e

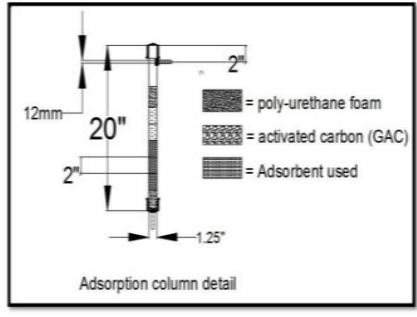

Fig $1 b$

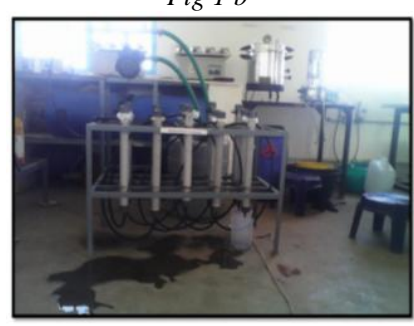

Fig $1 d$

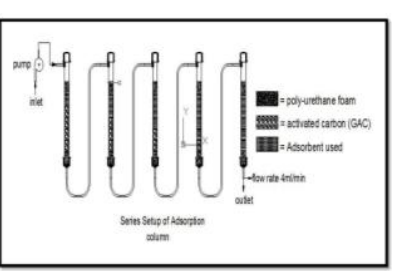

Fig $1 f$
Fig. 1.Adsorption tests set up (a) CADD model of adsorption column (b) adsorption column detail (c) Complete setup of adsorption column (d) Series connection of adsorption column (e) Individual connection of adsorption column (f) CADD model of series connection

\section{RESULT AND DISCUSSION}

The properties of the raw water before and after treatment are presented in Table 1. These results were evaluated, so as to measure the impact of using alternative adsorbents for the treatment of the same water sample.

TABLE- I : Properties of the collected water before and after treatment

\begin{tabular}{|c|c|c|c|c|c|}
\hline \multirow[b]{2}{*}{ Parameters } & \multirow[b]{2}{*}{$\begin{array}{l}\text { Initia } \\
\text { l } \\
\text { value }\end{array}$} & \multicolumn{4}{|c|}{ Optimum \% } \\
\hline & & $\begin{array}{l}80 \% \\
\text { sugarcane } \\
\text { bagasse }\end{array}$ & $\begin{array}{l}80 \% \\
\text { Saw } \\
\text { Dust }\end{array}$ & $\begin{array}{l}100 \% \\
\text { maize }\end{array}$ & $\begin{array}{l}80 \% \\
\text { Lime } \\
\text { Ston }\end{array}$ \\
\hline
\end{tabular}

\begin{tabular}{|l|l|l|l|l|l|}
\hline & & & & & e \\
\hline $\mathrm{pH}$ & 9.3 & 6.57 & 9.03 & 7.4 & 10.08 \\
\hline Transmittance & $18 \%$ & $48 \%$ & $64 \%$ & $98 \%$ & $99 \%$ \\
\hline Conductivity & $\begin{array}{l}18.98 \\
\mathrm{mS}\end{array}$ & $14.5 \mathrm{mS}$ & $12.92 \mathrm{mS}$ & $17 \mathrm{mS}$ & $\begin{array}{l}11.2 \\
\mathrm{mS}\end{array}$ \\
\hline Turbidity & $\begin{array}{l}14.90 \\
\mathrm{NTU}\end{array}$ & $\mathrm{Nil}$ & $1.4 \mathrm{NTU}$ & $\begin{array}{l}0.2 \\
\mathrm{NTU}\end{array}$ & $\mathrm{Nil}$ \\
\hline Absorbance & 0.74 & 0.13 & 0.19 & 0 & 0 \\
\hline COD & $\begin{array}{l}510 \\
\mathrm{mg} / 1\end{array}$ & $70 \mathrm{mg} / \mathrm{l}$ & $190 \mathrm{mg} / 1$ & $30 \mathrm{mg} / 1$ & $\mathrm{Nil}$ \\
\hline TDS & $\begin{array}{l}2.54 \\
\mathrm{ppt}\end{array}$ & $1.120 \mathrm{ppt}$ & $2.25 \mathrm{ppt}$ & $\begin{array}{l}2.18 \mathrm{pp} \\
\mathrm{t}\end{array}$ & $\mathrm{Nil}$ \\
\hline Chromium & $\begin{array}{l}0.36 \\
\mathrm{mg} / \mathrm{l}\end{array}$ & $\mathrm{Nil}$ & $\mathrm{Nil}$ & $\mathrm{Nil}$ & Nil \\
\hline Iron & $3 \mathrm{mg} / \mathrm{l}$ & $0.6 \mathrm{mg} / 1$ & $0.25 \mathrm{mg} / 1$ & $\mathrm{Nil}$ & Nil \\
\hline
\end{tabular}

\section{A. Effect of Sugarcane Bagasse}

In adsorption process, the sugarcane bagasse was added along with the activated carbon in different percentage proportions of $(100,0),(80,20),(60,40),(40,60)$ and $(20,80)$. The results showing the effect of sugarcane bagasse on the water properties is shown in Figure 2. It can be seen that the optimum dosage was found at $80 \%$ sugarcane bagasse and $20 \%$ activated carbon as adsorbent. When sugarcane bagasse was used as adsorbent, the $\mathrm{pH}$ reduced to 6.57 , which is similar to that obtained with distilled water. The transmittance was obtained as $48 \%$, which is sufficient for discharge. Also, the conductivity of the solution reached 14.5 $\mathrm{mS}$ for the optimum dosage. The turbidity of the waste water was completely removed. The absorbance value obtained was 0.13 , it was obtained using a photometer. According to the PCB norms, the value of COD must be less than $250 \mathrm{mg} / \mathrm{lit}$. When sugarcane bagasse was used as adsorbent, the COD value reached $70 \mathrm{mg} / \mathrm{lit}$, which was within the specified limits. The chromium was removed $100 \%$, so it is safe for discharging into the streams. The value of iron reached $0.6 \mathrm{mg} / \mathrm{lit}$ as per the norms, it should be less than 3 $\mathrm{mg} / \mathrm{lit}$, so it is adequate for discharging. The sulfate value reached $22.69 \mathrm{mg} / \mathrm{lit}$ and the TDS reached $1.120 \mathrm{PPT}$.

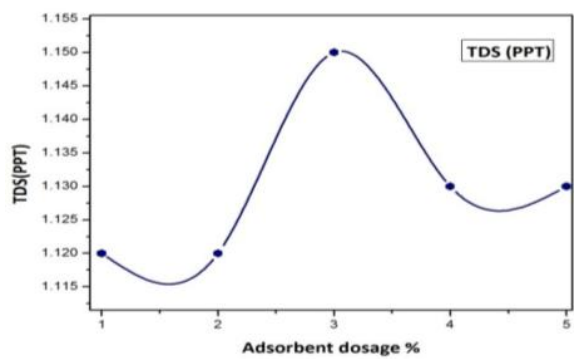

Fig 2 a

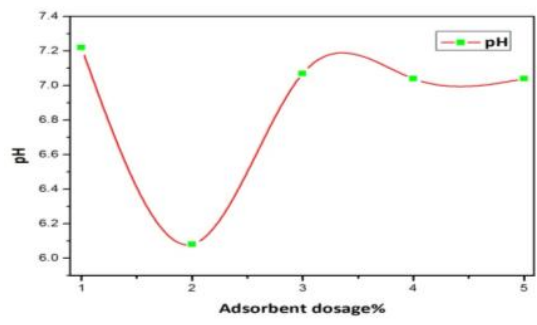

Fig 2 b 


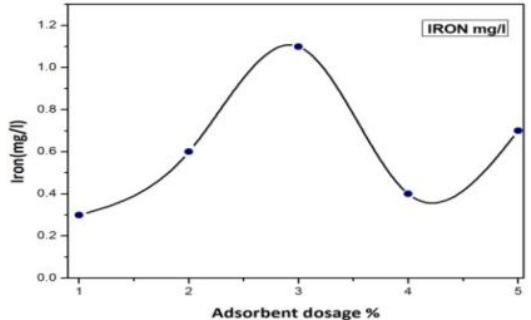

Fig 2 c

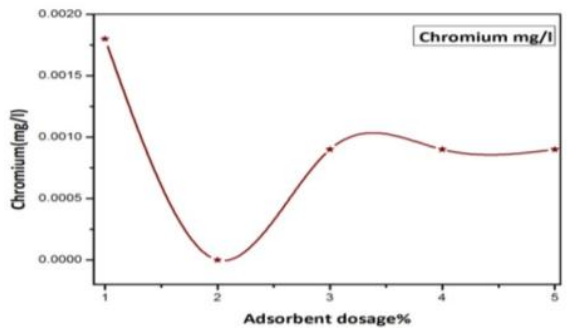

Fig $2 d$

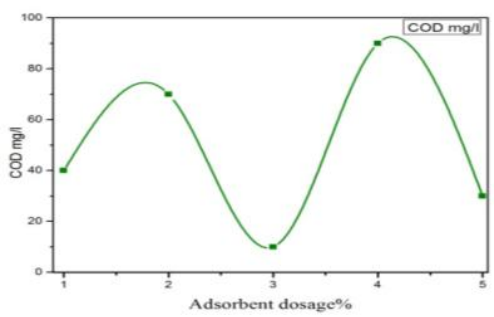

Fig 2 e

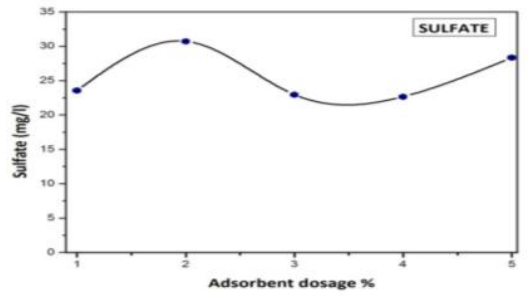

Fig $2 f$

Fig. 2.Effect of sugarcane bagasse on (a) TDS (b) pH (c) Iron (d) chromium (e) COD (f) sulphate

\section{B. Effect of Saw Dust}

Similarly, for the adsorption process, saw dust was added along with the activated carbon in different percentage of $(100,0),(80,20),(60,40),(40,60)$ and $(20,80)$. Figure 3 shows the properties of the water after being treated with proportion of sawdust and activated carbon as adsorbent. Also, it can be seen that the optimum dosage was at $80 \%$ saw dust and $20 \%$ activated carbon combination. When sawdust was used as adsorbent, the $\mathrm{pH}$ was reduced to 9.03 , and the transmittance was obtained as $64 \%$, which is sufficient for discharge. The conductivity of the solution reached $12.92 \mathrm{mS}$ for the optimum dosage. The turbidity of the treated sample reached the value of 1.4 NTU. The absorbance value obtained was 0.19. According to the PCB norms, the value of COD must be less than $250 \mathrm{mg} / \mathrm{lit}$. The COD value reached 190 $\mathrm{mg} / \mathrm{lit}$, and the chromium was removed $100 \%$, so it is safe for discharging into the streams. The value of iron has reached $0.25 \mathrm{mg} / \mathrm{lit}$, which is similar to the value of drinking water. The sulfate value reached $48.84 \mathrm{mg} / \mathrm{lit}$, and the TDS reached 2.25 PPT.

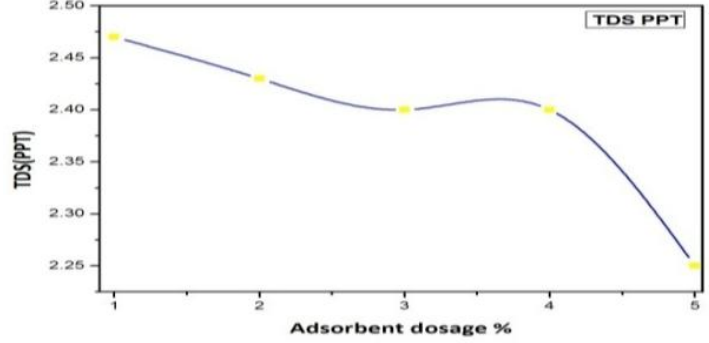

Fig 3 a

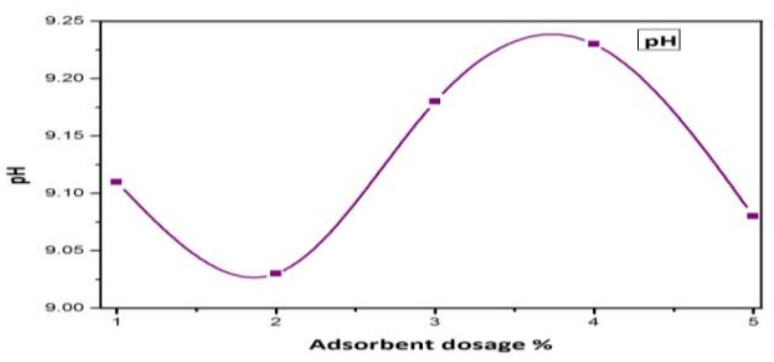

Fig $3 b$

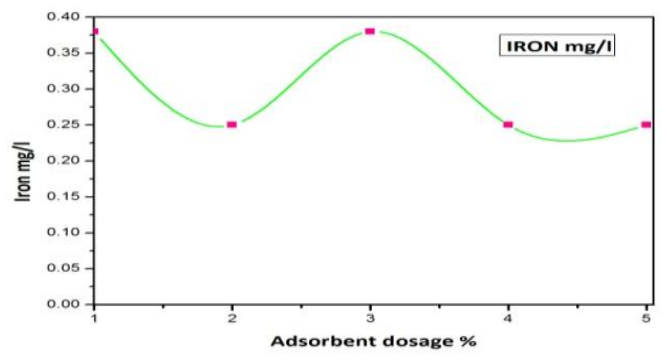

Fig 3 c
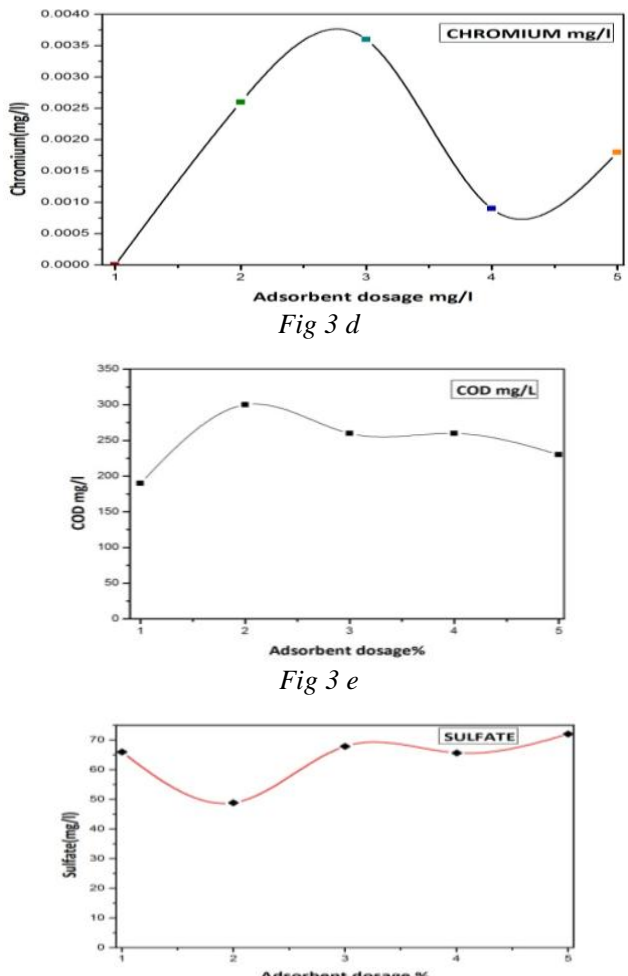

Fig 3 f

Fig. 3.Effect of sawdust on (a) TDS (b) pH (c) Iron (d) chromium (e) COD (f) sulphate 


\section{Effect of Maize}

In similar manner, maize was added along with the activated carbon in different percentage at $(100,0),(80,20),(60,40)$, $(40,60)$ and $(20,80)$. From the results (Figure 4$)$, it can be seen that the optimum dosage was found at $100 \%$ maize and $0 \%$ activated carbon proportion. When maize was used as adsorbent, the $\mathrm{pH}$ was reduced to 7.4 , which is similar to the distilled water. The transmittance was obtained as $98 \%$, which is similar to drinking water. The conductivity of the solution reached $17.0 \mathrm{mS}$ for the optimum dosage. The turbidity of the treated sample becomes less than the discharging norms of the industrial waste water, and reached the value of 0.2 NTU. The absorbance value obtained was zero. According to the PCB norms, the value of COD must be less than 250mg/lit. Also, the COD value reached $30 \mathrm{mg} / \mathrm{lit}$. The iron and chromium was completely removed, so it is safe for discharging into the streams. The sulfate value reached $26.37 \mathrm{mg} / \mathrm{lit}$ and the TDS reached 2.18 PPT.

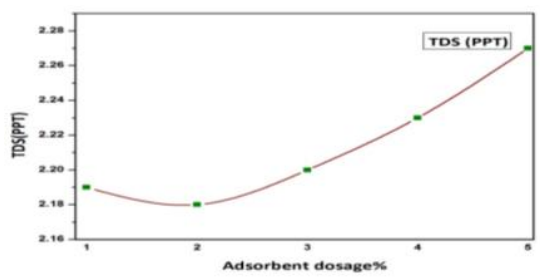

Fig 4 a

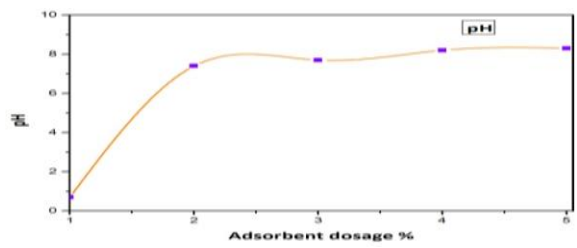

Fig $4 b$
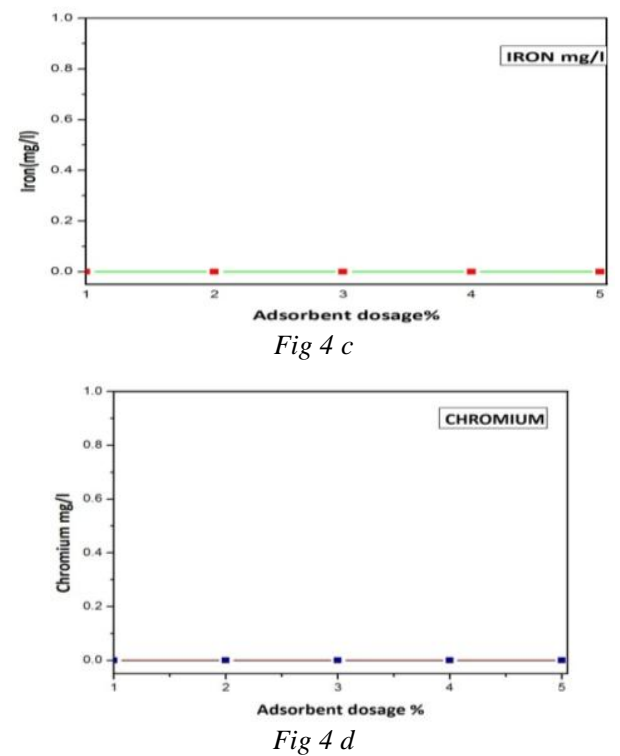
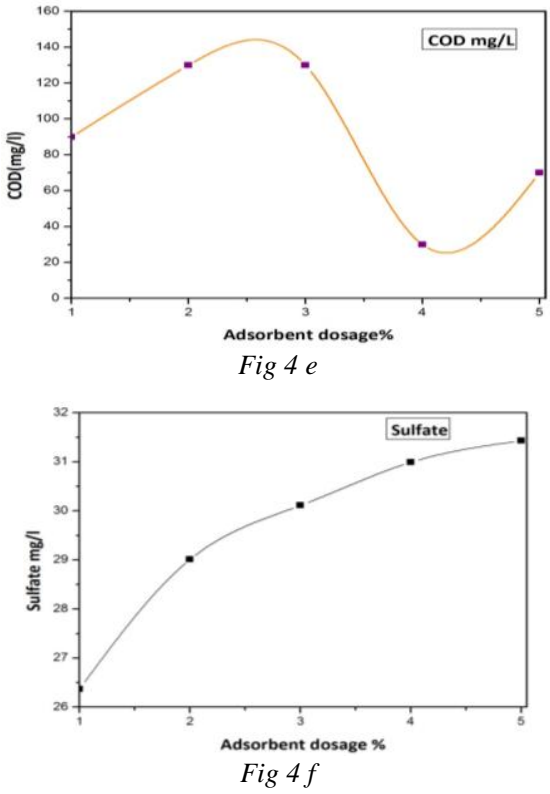

Fig. 4.Effect of maize on (a) TDS (b) pH (c) Iron (d) chromium (e) COD (f) sulphate

\section{Effect of Limestone}

Lime stone was also added along with the activated carbon in different percentage at $(100,0),(80,20),(60,40),(40,60)$ and $(20,80)$. From the results (Figure 5$)$, it can be seen that the optimum dosage was found at $80 \%$ lime stone and $20 \%$ activated carbon proportion. When lime stone was used as adsorbent, the $\mathrm{pH}$ reduced to 10.08 , which is sufficient for discharge. The transmittance was obtained as $99 \%$, which is similar to that of drinking water. The conductivity of the solution reached $11.2 \mathrm{mS}$ for the optimum dosage. The turbidity of the treated sample was less than the 129 discharging norms of the industrial waste water. Also, the absorbance value obtained was zero. According to the PCB norms, the value of COD must be less than $250 \mathrm{mg} / \mathrm{lit}$. Also, the COD was removed completely.

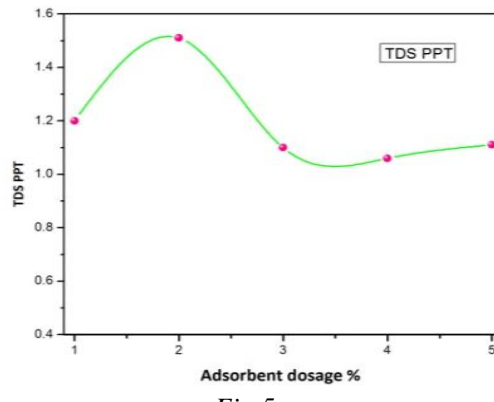

Fig 5 a

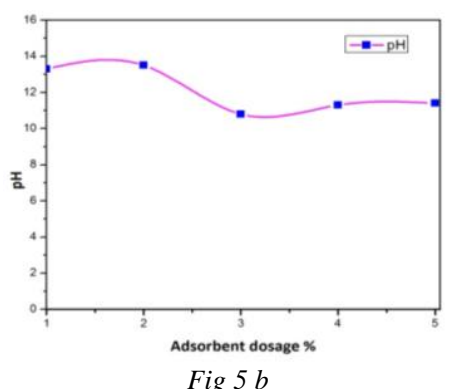

Fig $5 b$ 


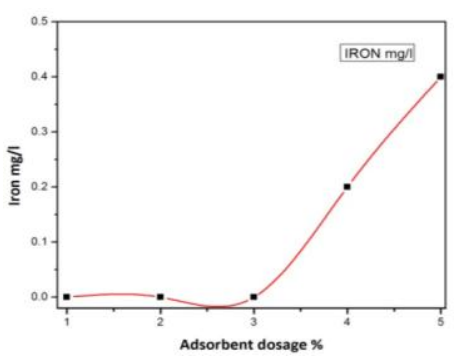

Fig $5 c$
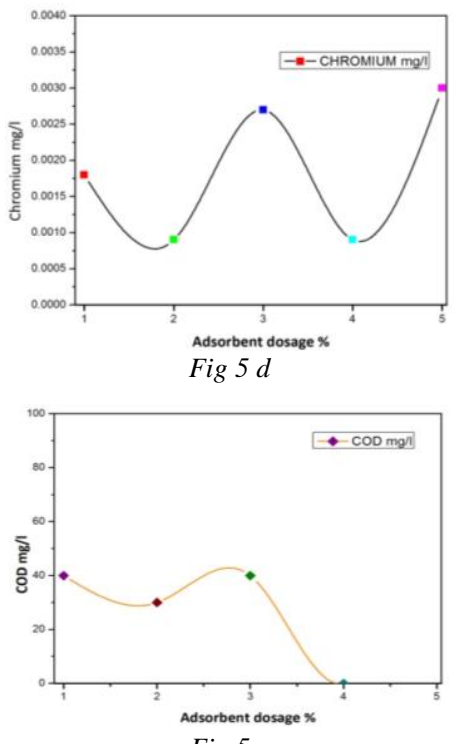

Fig $5 e$

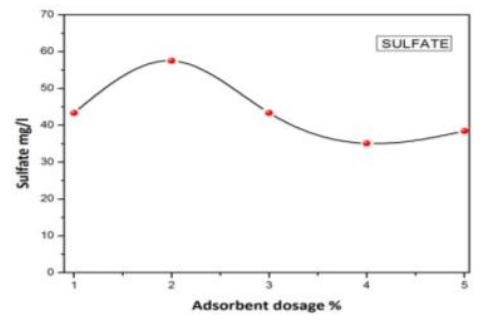

Fig $5 f$

Fig. 5.Effect of limestone on (a) TDS (b) pH (c) Iron (d) chromium (e) COD (f) sulphate

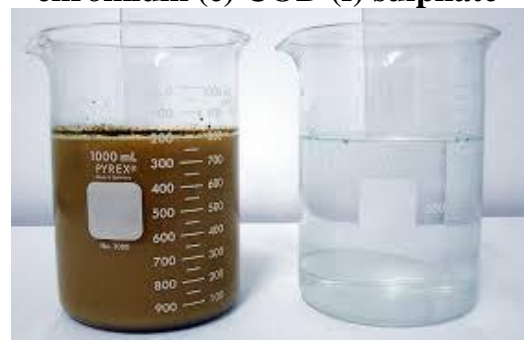

Fig. 6 Textile water Before and After Treatment

\section{CONCLUSION}

The experimental investigations suggests that the abundantly available and low-cost materials like sugarcane bagasse, saw dust, maize, lime stone can be effectively used as a adsorbent materials. The optimum replacement of activated carbon with $80 \%$ of sugarcane bagasse, saw dust, lime stone gives better treated water. And $100 \%$ replacement of maize performed better than other absorbents. These materials are abundantly available, high in efficiency, eco-friendly and cost-wise economic. Therefore, for industrial effluents treatment before it is discharged into the natural water bodies, so that it may not cause water and soil pollution, natural material such as those used in this study could be used for wastewater treatment on industrial scale. The maximum removal of turbidity for the sample was achieved as $90 \%$. So, it can be suggested that, we can use the locally available natural adsorbent to treat the low turbid wastewater, being cost effective and environment friendly. The parameters such as $\mathrm{pH}$, heavy metal concentration, contact time, absorbent dosage were affected the absorbent's removal efficiency. Waste water disposal into the environment is harmful and could result in health problems. Therefore, it is necessary to propose cost-effective treatment methods, which can curtail this problem. .

\section{REFERENCES}

1. Allegre C., Mouline P., Maissey M. and Charbit F. (2006), 'Treatment and reuse of reactive dyeing effluents', Journal of Membrane Science, Vol. 269, pp. 15-34.

2. Asamudo N.U., Daba A.S. and Ezeronyel O.U. (2005), 'Bioremediation of textile effluent using Phanerochaetechrysosporium', African Journal of Biotechnology, Vol. 4, pp. 1548-1553.

3. Bhattacharyya K.G. and Sharma A. (2005), 'Kinetics and thermodynamics of methylene blue adsorption on Neem (Azadirachta indica) leaf powder', Dyes and Pigments, Vol. 65, pp. 51 - 59

4. Chavan R.B. (2001), 'Environment-friendly dyeing processing for cotton', Indian Journal of Fiber and Textile Research, Vol. 4, pp 239242.

5. Ghanshyam Pandhare, Nikhilesh Trivedi, NitinKanse and Dawande S.D. (2013), 'Synthesis of Low Cost Adsorbent from Azadirachta Indica (Neem) Leaf Powder', International Journal of Advanced Engineering Research and Studies, Vol. 2, No. 2, pp. 29-31.

6. Nelliyat Prakash (2007), 'Industrial Growth and Environmental Degradation: A Case Study of Tirupur Textile Cluster', Working paper No.17, Madras School of Economics, Chennai.

7. Robinson T., McMullan G., Marchant R. and Nigam P. (1997), 'Remediation of dyes in textile effluent: a critical review on current treatment technologies with a proposed alternative', Colourage, Vol. 46, pp. 247-255.

8. Sule A.D. and Bardhan M.K. (1999), 'Objective evaluation of feel and handle appearance and tailor ability of fabrics. Part II: the KES-FB system of Kawabata', Colourage, Vol. 46, pp. 23-35.

9. Swaminathan and Jeyaranjan J. (1995), 'The Knitwear Cluster in Tirupur: an Indian Industrial District in the Making', Working Paper No.126, Madras Institute of Development Studies, Chennai.

10. Walker G.M. and Weatherly L.R. (1997), 'Adsorption of acid dyes onto granular activated carbon in fixed beds', Journal of Water Resource, Vol. 31, pp. 2093-2101.

\section{AUTHORS PROFILE}

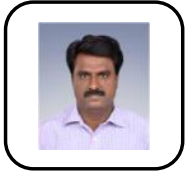

Dr. Muthukannan M completed his Ph.D in Civil Engineering in Anna University, Chennai in the year 2010. He completed Master of Engineering in the field of Transportation Engineering and Management in College of Engineering, Guindy, Chennai in the year 2004. He completed his Bachelor of Engineering under Madurai Kamarajar University in the year 2000 . He is presently working as a Professor in Civil Engineering department at Kalasalingam University, Tamilnadu, India. He is guiding for many Ph.D scholars in the field of transporation engineering and computer applications in transportation network using graph theory. He has published various quality papers in the reputed journals. His main thrust research areas are transportation network design, transport management and travel demand management. 
Mr. Arunkumar $\mathbf{K}$ is pursuing his $\mathrm{PhD}$ in Department of Civil Engineering from Kalasalingam Academy of Research and Education, Krishnankoil, India. He pursued his Bachelor degree in Civil Engineering from Sengunthar Engineering College, Tiruchengode, affiliated to Anna University, Chennai. Also, he pursued Master of Technology in Structural Engineering from Kalasalingam University, Krishnankoil. His areas of interests are Concrete Technology and Ferrocement Technology.

Ms. Maheswari $\mathbf{M}$ is working as an assistant professor in Department of Civil Engineering, Kalasalingam Institute of Technology, Krishnankoil. She pursued his Bachelor degree in Civil Engineering from Ratnavel college of Engineering and Technology, affiliated to Anna University, Chennai. Also, he pursued Masters in Environmental Engineering from Anna University, BIT campus. Her areas of interests are Water Technology and Environmental Engineering. 